JOURNAL OF ENGINEERING SCIENCES

ЖУРНАЛ ІНЖЕНЕРНИХ НАУК

ЖУРНАЛ ИНЖЕНЕРНЫХ НАУК

Web site: http://jes.sumdu.edu.ua

DOI: $10.21272 /$ jes.2017.4(2).g6

Volume 4, Issue 2 (2017)

UDC $66.021+66.048 .3$

\title{
Modelling of the vertical migration process of phosphogypsum components in the soil profile
}

Chernysh Ye. Yu., Plyatsuk L. D., Yakhnenko O. M., Trunova I. O.*

Sumy State University, 2 Rymskogo-Korsakova St., 40007, Sumy, Ukraine

Article info:

Paper received:

The final version of the paper received:

Paper accepted online:
October 5, 2017

November 26, 2017

December 2, 2017
*Corresponding Author's Address:

inna.trunova@ecolog.sumdu.edu.ua

\begin{abstract}
This paper focuses on the study of the process of vertical migration of phosphogypsum components according to the soil profile. The qualitative and quantitative identification of main biogenic elements (phosphorus, sulphur, calcium etc) and heavy metals in lysimetric solutions from various horizons while getting on the surface of soil solutions containing phosphogypsum components is carried out by means of designed laboratory and experimental complex. The mineral hard soil fraction is also analysed. According to the results of the X-ray diffractometrical researches, the carbonates with heavy metals in their structure, caused by the ion-exchange with $\mathrm{Ca} 2+$, were found in the mineral structure of the illuvial horizon soil samples. The results of experimental modeling indicate significant changes in the chemical parameters of groundwater, which are obtained by passing water with phosphogypsum particles on a model soil profile, which makes it easy to track the input data. In the upper part of the profile after 1000 hours and for the first speed of the infiltration process, the constant moisture level was $25,6 \%$, after the second speed of infiltration, it rose to $29.1 \%$. Noted that the highest concentration of biogenic elements (calcium, sulfur, potassium) was found in lysimetric solutions obtained from the humus and eluvial horizons. In addition, it is determined that iron is present up to $5 \%$, nickel - within the range of 1-3\%, and copper - up to $1 \%$. It should be noted that the biochemical transformations of silicon influence the fractional distribution of heavy metals, which can be fixed by sorption-sedimentation mechanisms in silica, oligo and polysilicon compounds, as well as in crystalline lattice structures of clay minerals, quartz, etc. The model of soil and geochemical situation was formed according to the soil profile under the influence of the phosphogypsum within the three-dimensional surface, developed with the help of the stochastic reconstructions based on the images of the scan electron microscopes.
\end{abstract}

Keywords: modeling, vertical migration, moistening, phosphogypsum, heavy metals, soil profile.

\section{Introduction}

The environmental concerns associated with phosphogypsum stacks include fluoride uptake, ground and surface water pollution if located nearby. Main vectors for their transport into the environment are wind and water erosion, infiltration, leaching into surface and ground water and airborne emissions of gaseous and radioactive elements. Fine particles of phosphogypsum can be picked up and transported by wind and vehicular traffic on stacks into adjacent areas. Dust particles containing fluoride is a concern for operational and non operational stacks. Elevated levels of fluoride have been found in soil/vegetation adjacent to the stacks.

Disposal of phosphogypsum on land may pose seepage problems beneath the repositories or the process water holding ponds if not lined or controlled properly. Phosphogypsum stacks up to a height of $20 \mathrm{~m}$ are in operation in the country. The water stock from phosphogypsum cannot be discharged as such as it contains significant quantities of fluorine and phosphates as $\mathrm{P}_{2} \mathrm{O}_{5}$. The outer dikes are generally earthen dikes designed to prevent the escape of contaminated water into nearby streams. Fluoride contaminant present in phosphogypsum may attack silicate minerals and dissolve them [1].

\section{Background}

The huge amount of scientific works was dedicated to the studying of the environmental contamination in phosphogypsus (PG) heaps keeping areas or during its direct application in the agriculture and road building. It is caused by the possibility of application of certain amount of heavy metals (HM) along with phosphogypsum into ecosystems amplifying their migration in the soil environment by means of soil solution souring with phosphogypsum, getting into trophic chains, and increasing of anthropogenic pressure on ecosystems [2-9]. 
A set of known heap monitoring directions, including PG and anthropogenic massifs, deal only with geodesic studies. The aim of such a geoecological monitoring is a geomechanical processes status that takes place in massifs to avoid uncontrollable catastrophical processes as landshifts and landslips, and to guarantee the forming quarries and heaps side stability $[10,11]$.

Another application of geodesic studies is the security monitoring during the formation of PG heaps including hydromechanical, geodesic and technological components [12].

\section{The objectives of the study}

The aim is to study the process of vertical migration of PG components according to the soil profile.

The following tasks were included:

- to elaborate the laboratory and experimental complex aimed at migration process modeling and PG components transformation in the soil profile;

- to make a model of grey forest soils according to the depth with a formation of a frontal moisturizing progression;

- to make a model of migratory process connected with PG components during filtration through soil profile of water containing fine PG elements.

\section{Materials and methods}

Complicated mechanisms of chemical elements distribution in soils under influence of natural and anthropogenic factors intricate the process of prediction concerning location or distribution of some chemical substances in the soil profile. It is confirmed by the results as for indication of heavy metals content in the natural soil solutions from adjacent to a humid territories. It was determined that under the influence of atmospheric precipitation, evaporation and transpiration of plant groups, the dynamics of change in concentration of trace elements in soil solutions may change by more than an order of magnitude. Under analogical conditions, the concentration of main macroelemental ions $\left(\mathrm{Ca}^{2+}, \mathrm{Mg}^{2+}, \mathrm{K}^{+}, \mathrm{NO}^{-3} \mathrm{i} \mathrm{PO}_{4}{ }^{3-}\right)$ is less changeable. Accordingly, the module of laboratory-experimental complex was elaborated for the regulation of multi-factored effect that is caused by PG and its composite materials to biogenic elements and heavy metals migration.

Figure 1 shows elaborated laboratory-experimental complex.

The module of the soil profile, created accordingly to natural genetic horizons from a territory of natural ecosystems near the PG dumb, was in the tube of organic glass. The measurement of module work part: length $\times$ width $\times$ height: $40 \mathrm{~cm} \times 30 \mathrm{~cm} \times 75 \mathrm{~cm}$.

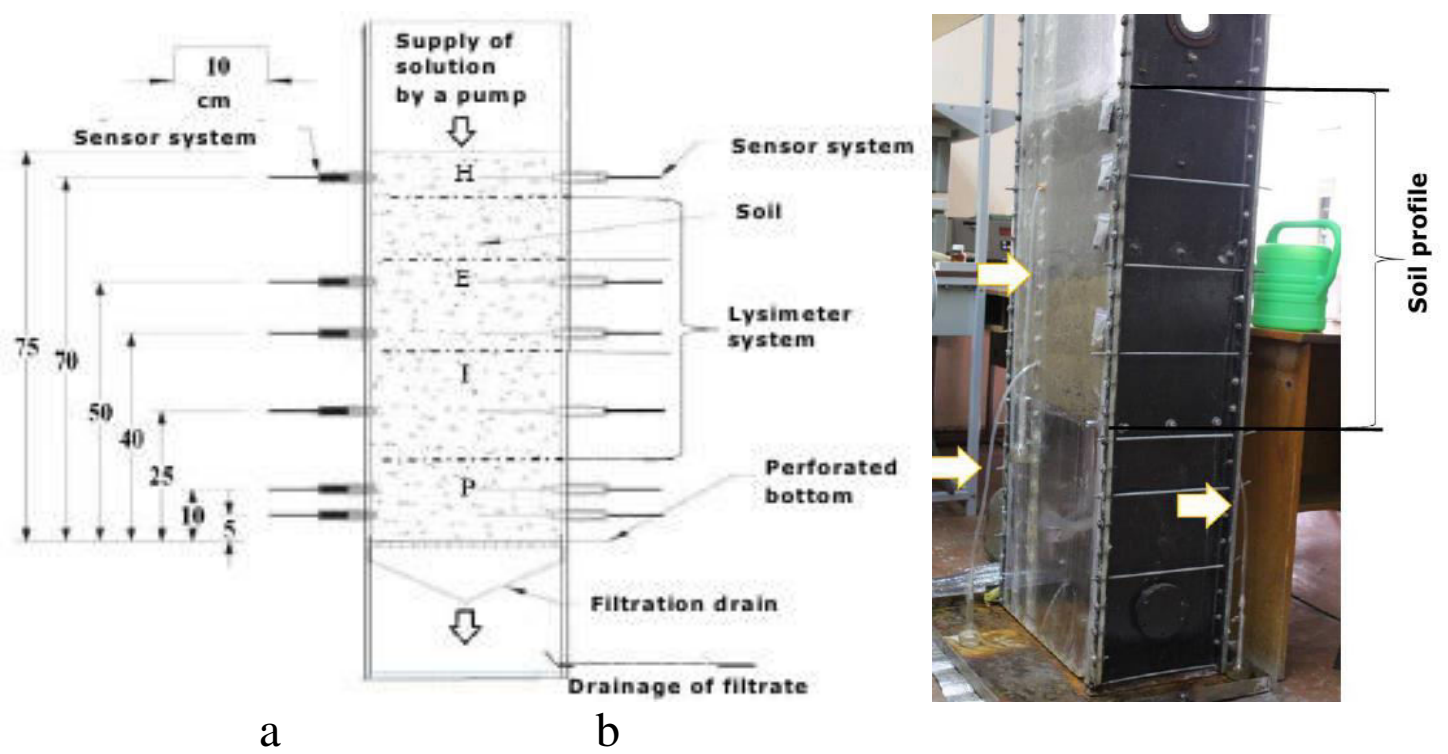

Figure 1 - laboratory-experimental complex concerning a modeling of migration and transformation process of the phosphogypsus components in the soil profile:

$\mathrm{a}$ - the scheme of the laboratory-experimental complex with soil horizons: $\mathrm{H}$ - humus; E - eluvial; I - illuvial; D - maternal breed; $\mathrm{b}$ - the photo of the laboratory-experimental complex; the channels of lysimeter solution are indicated with arrows

A module surface with soil was sprinkled with phosphogypsis solution. The sensor system contained detectors of moisture and temperature. Microcontroller Arduino Uno (licensed) was used for rate control. A constant supply of solution by a pump to the top surface of the soil was implemented with the usage of peristaltic pump Masterflex ${ }^{\circledR}$ L / S. A selection of the filtrated solu- tion samples was implemented in the depth of the soil profile 10, 20, 40 and $60 \mathrm{~cm}$ due to lysimeter. During this process, the drainage of the solution from the lysimeters took place according to a principle of drift with help of output channels, that ended with polymeric tubes.

Lysimeters were pallets that had a form of a funnel (truncated conus with a trivet on the top). These pallets 
were connected with an output of water receiver with the help of a small glass pipe. The funnels were filled up with a drainage and were inserted into other tubes according to the depth of the soil profile.

The soil in the lysimeters was in suspended state, where the forces of a capillary adhesion on the border of the soil-drainage or soil-air are absent, that is why the water drain was slowing down [13].

There was carried out qualitative and quantitative determination of the main biogenic elements (phosphorus, sulfur, calcium, etc.) and heavy metals in lysimetric solutions from various horizons with the help of X-ray fluorescence analysis method, and there was controlled $\mathrm{pH}$ value. In addition, the diffractometrical method helped to perform an analysis of the mineral solid fraction of the soil beyond the genetic horizons.

\section{Results}

Measuring the moisture content in different places on the soil surface showed that the water distribution is relatively equal. The inflow and outflow of aqueous solution for the soil profile are shown in Fig. 2.

In this study, there were used two stages of the water inflow containing fine-dispersed particles of phosphogypsum. The first stage included a constant inflow speed $9 \cdot 10^{-8} \mathrm{~m} / \mathrm{s}$ as long as there was no persistent leak, which required about 1250 hours. At the second stage, a higher speed was applied $5 \cdot 10^{-7} \mathrm{~m} / \mathrm{s}$ and lasted as long as no persistent leakage was observed after about 2000 hours.

According to the results of X-ray fluorescence analysis, the elements distribution in lysimetric solutions according to the horizons was determined (Fig. 3).

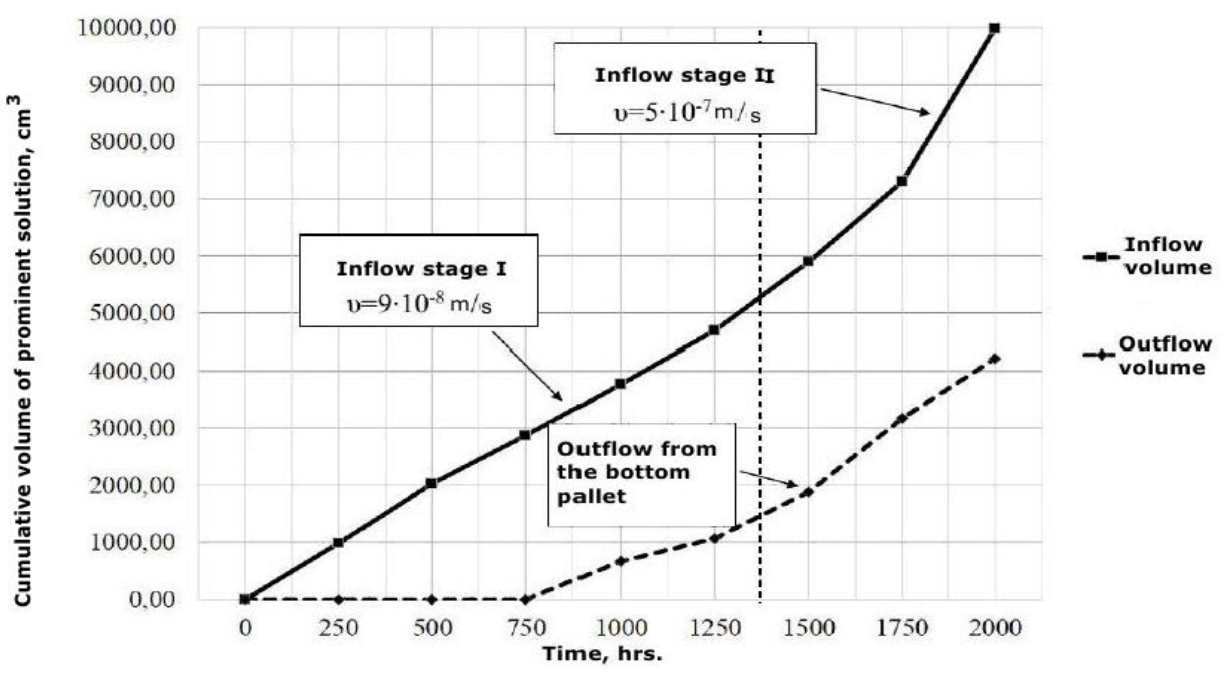

Figure 2 - The inflow and outflow of aqueous solution for the soil profile model
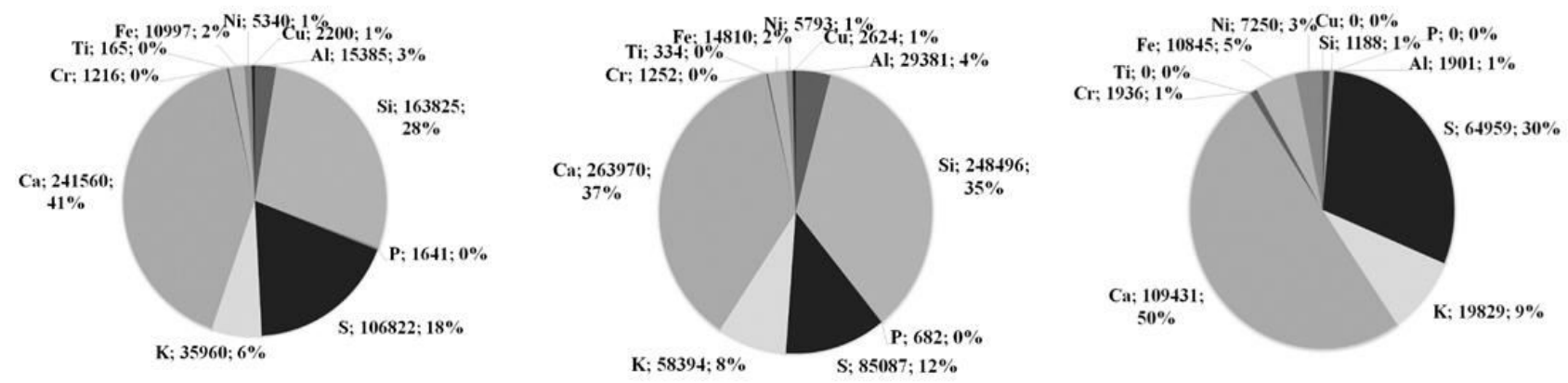

Figure 3 - The ratio of elements in lysimetric solutions samples from different depths based on the soil profile model, \%: a - from the genetic horizon $H, 10 \mathrm{~cm} ; B$ - from the genetic horizon $E, 20 \mathrm{~cm} ; c$-from the genetic horizon $I$ passing to $P, 40 \mathrm{~cm}$

The dynamics of the main elements distribution in lysometric solutions is presented in Table 1.

As can be seen from Fig. 3 and Table 1, the highest concentration of biogenic elements (calcium, sulfur, potassium) was found in lysimetric solutions obtained from the humus and eluvial horizons. In addition, it is determined that iron is present up to $5 \%$, nickel - within the range of $1-3 \%$, and copper - up to $1 \%$. In the whole, the concentration of these elements fluctuates in the abovementioned limits according to all rare samples from different genetic horizons. In lysimetric solutions, no lead and cadmium were detected, which is the evidence of absence of water-soluble forms of these HM in soils that were irrigated with water containing fine-dispersed parti- 
cles of phosphogypsum. This confirms the results of the previous field studies in the territory of the phosphogypsum dump [14], when moving forms of $\mathrm{Pb}$ and $\mathrm{Cd}$ were detected only under the influence of ammonium-acetate buffer solution.

Table 1 - Results of the comparative analysis of the peak intensity of chemical elements in the lysimetric solutions beyond the horizons of the soil profile model (the color indicates the intensity change of the element in the analyzed samples)

\begin{tabular}{|c|c|c|c|c|}
\hline \multirow{2}{*}{$Z$} & \multirow{2}{*}{ Element } & Intensity & \multicolumn{2}{|c|}{ Change in \% } \\
\cline { 3 - 5 } & & $E$ & $H$ & $I$ \\
\hline 13 & $\mathrm{Al}$ & 29381 & 48 & 94 \\
\hline 14 & $\mathrm{Si}$ & 248496 & 34 & -100 \\
\hline 15 & $\mathrm{P}$ & 682 & 141 & - \\
\hline 16 & $\mathrm{~S}$ & 85087 & 26 & 24 \\
\hline 19 & $\mathrm{~K}$ & 58394 & 38 & 66 \\
\hline 20 & $\mathrm{Ca}$ & 263970 & 8 & 59 \\
\hline 22 & $\mathrm{Ti}$ & 334 & 51 & - \\
\hline 24 & $\mathrm{Cr}$ & 1252 & 3 & 55 \\
\hline 26 & $\mathrm{Fe}$ & 14810 & 26 & 27 \\
\hline 28 & $\mathrm{Ni}$ & 5793 & 8 & 25 \\
\hline 39 & $\mathrm{Cu}$ & 2624 & 16 & - \\
\hline
\end{tabular}

It should be noted that the samples of lysimetric solutions haven't been taken from the $P$ horizon because of the absence of the lysimeter drain that was caused by the water-resistant properties of the clay material within this horizon. The $p H$ value of the lysimetric solutions ranged within the limits of 4.7-5.8 for the $H, E$ and $I$ genetic horizon samples, indicating the acid reactions within the soil medium. However, after the measuring of the $P G$ value of the $P$ horizon soil extract (10 and $5 \mathrm{~cm}$ from the basis) indexes came up to the neutral ones (6.4-6.9).

\section{Discussion}

The dynamics of the moistening front during the infiltration process is shown in the Fig. 6 .

With the reference to Figure 6 one can understand that it would take about 500-550 hours for the moistened surface to reach the basis of the profile. It is also confirmed by the analysis of the diagram № 4, where the drain wasn't observed for 520 hours. It happens due to the marginal effects within the moisture distribution profile. It didn't come out of the soil until the profile basis was almost entirely soaked, that was caused by the capillary rupture effect. The capillary rupture takes place when there is a contrast between the size of the interstices located at the horizon interfaces (i.e. fine-grained clay rocks are situated above the relatively large holes within the corresponding plate).

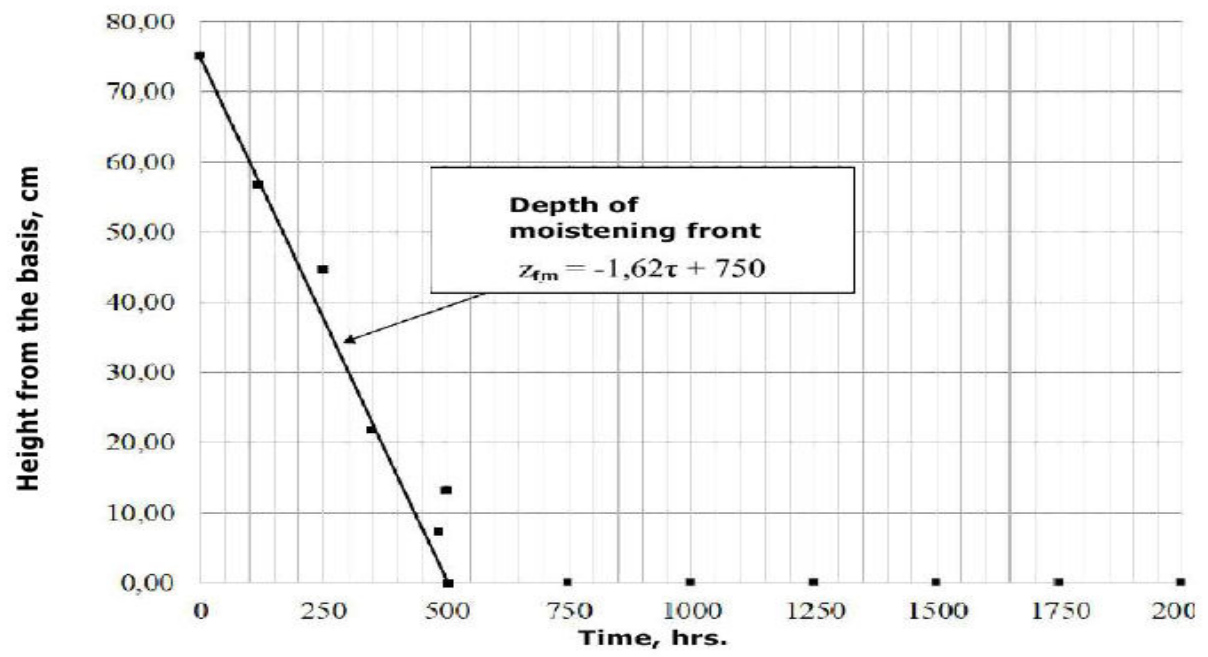

Figure 4 - The front moistening progression

In the upper part of the profile after 1000 hours and for the first speed of the infiltration process, the constant moisture level was $25.6 \%$, after the second speed of infiltration, it rose to $29.1 \%$. The two above mentioned stages illustrate that a single pressure gradient is present in the upper part of the soil profile (i. e. the soaking doesn't change with the depth). In this case, the hydraulic conductivity is equal to the discharges.

Taking into account the data obtained, the model of soil and geochemical situation was build according to the soil profile (Fig. 5) under the influence of the $P G$ within the three-dimensional surface, developed with the help of the stochastic reconstructions based on the images of the
SEM (scan electron microscopes), high-resolution photographs (21.0 Mp) and Autodesk 3DS Max software.

According to the results of the X-ray diffractometrical researches, the carbonates with heavy metals in their structure, caused by the ion-exchange with $\mathrm{Ca}^{2+}$, were found in the mineral structure of the illuvial horizon soil samples. Furthermore, in the lysimetric solutions within this horizon the part of Ca made up 48-53\%. The significant content of $\mathrm{Ca}$ in the solutions let us conclude as for the possible biochemical processes of its releasing from the phosphogypsum structure due to the action of the rhizosphere microorganisms. It creates the subsurface 
barrier for the migration of toxins downward within the profile.

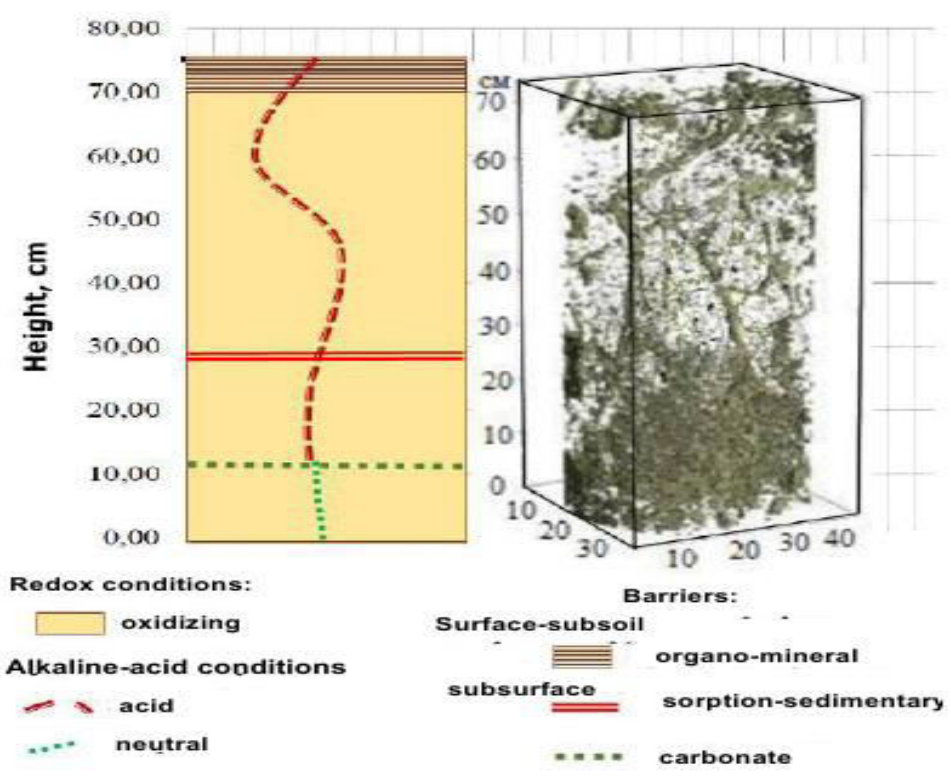

Figure 5 - The model of soil and geochemical situation with the structure of the interstices in the fine-grained clay rocks according to the model profile

We determined the stable compounds of $\mathrm{SiO}_{2}$ aluminosilicates, $\mathrm{AlO}_{3} \cdot 2 \mathrm{SiO}_{2} \cdot 3 \mathrm{H}_{2} \mathrm{O}$ and soluble $\mathrm{FeO}$ iron oxide forms, that correlates with the data on lysometric solutions. Thus, in the solution of the ilevial horizon there were $5 \%$ of the total $\mathrm{Fe}$ content, and $\mathrm{Si}$ in the water soluble form is only at the level of $1 \%$. In the humus horizon and eluvial, based on the results of lysometric analysis, water soluble forms of silicon (24-31 and 31-38\% respectively) were found. It should be noted that the hydroxides and iron oxides play an important role in the sorption of $\mathrm{HM}$, it is related with such formations as $\mathrm{FeOMe}$, (FeO) $2 \mathrm{Me}, \mathrm{FeOMeON}$, for example $\mathrm{PbFe}_{2} \mathrm{O}_{4}$.

The biochemical aspects of the metabolism of silicon are not fully understood today. Si can also interact with phosphogypsum components under the influence of biochemical factors (bacterial metabolites) [15].

It should be noted that the biochemical transformations of silicon influence the fractional distribution of HM, which can be fixed by sorption-sedimentation mechanisms in silica $\left(\mathrm{SiO}_{2} \cdot \mathrm{nH}_{2} \mathrm{O}\right)$, oligo and polysilicon compounds, as well as in crystalline lattice structures of clay minerals, quartz, etc.

It should also be noted that the significant content of sulfur compounds in water-soluble form (sulfate ions), which was observed in accordance with the results of the study, may be the result of the action of the biotic component of the soil complex on fine particles of PG, which came from the water in the profile of the model soil. Accordingly, this is a confirmation of the possibility of using the components of phosphogypsum in the metabolic activity of soil bios.

\section{Conclusions}

We accomplished the simulation of moisture of gray forest soils at depth during filtration through the soil profile of water containing fine particles of phosphogypsum. This made it possible to investigate the dynamics of the moisture front during the infiltration of the aqueous solution as a model of runoff of contaminated water from an array of $P G$ dumps.

The results of experimental modeling indicate significant changes in the chemical parameters of groundwater, which are obtained by passing water with PG particles on a model soil profile, which makes it easy to track the input data. The main changes in the soil system can be characterized as a change in $\mathrm{pH}$, an increase in dissolved ions, especially sulfates and phosphates, but also in metal ions, and an increase in dissolved silicon dioxide. Increased concentrations of many ligands lead to significant changes in the predicted equilibrium complexation. In this case, the highest concentration of nutrients (calcium, sulfur, potassium) in soil solutions is obtained from the humus and eluvial horizons of the model soil profile.

One can assume that the most expressed growth of metal complexes with sulfate and phosphate leads to the formation of uncharged or negatively charged types of solutions that are likely to be more mobile in the aquifer than positively charged metals.

Although the results of the model should not be considered to be final, taking into account the various potential solid phases that may be formed, the general trend of predicted transformation reactions in the soil system indicates the precipitation reaction of various, and probably multicomponent solids, that should be expected directly in the runoff of polluted water from the PG waste stack. 


\section{References}

1. Guidelines for Management and Handling of Phosphogypsum Generated from Phosphoric Acid Plants (Final Draft). Central Pollution control board (Ministry of Environment \& Forests). Parivesh Bhawan (2012), available at: http://www.cpcb.nic.

2. Folek, S., Walawska, B., Wilczek, B., \& Miśkiewicz, J. (2011). Use of phosphogypsum in road construction. Polish Journal of Chemical Technology, Vol. 13, No 2, 18-22.

3. Shen, W., Zhou, M., Ma, W., Hu, J., \& Cai, Z. (2009). Investigation on the application of steel slagfly ash-phosphogypsum solidified material as road base material. Journal of hazardous materials, No 164 (1), 99-104.

4. Krainiuk, O. V., Buts, Yu. V., \& Kobzin, V. G. (2013). Do pytannia nebezpeky vidkhodiv promyslovosti pry budivnytstvi avtomobilnyh dorih: zb. nauk. pr. Budivnycztvo, materialoznavstvo, mashynobuduvannya, Vol. 1, Issue 71, 153-157.

5. Lyubimova, Y. N., Tersyn, V. A., et al. (2009). Otsenka vliyaniya stroitelstva dorogi s ispolzovaniyem fosfogypsa na zagryaznenye pochv. Byulleten Pochvennogo instytuta im. V. V. Dokuchaeva, No 63, 74-83.

6. Gorlov, A. A., Krechetov, P. P., \& Rogova, O. B. (2015). Vliyanye fosfogypsovyh dorog na fiziko-himicheskiye svoystva pochv. Mezhdunarodnaya nauchnaya konferenciya: K 100-letiyu so dnya rozhdeniya akademyka G. V. Dobrovolskogo, pp. 3435.

7. Degirmenci, N., Okucu, A., \& Turabi, A. (2007). Application of phosphogypsum in soil stabilization. Building and Environment, Vol. 42, No 9., 3393-3398.

8. Papastefanou, C., Stoulos, S., Ioannidou, A., \& Manolopoulou, M. (2006). The application of phosphogypsum in agriculture and the radiological impact. Journal of Environmental Radioactivity, Vol. 89, No 2, 188-198.

9. Belyuchenko, Y. S. (2014). Osobennosti mineralnyh othodov v tselesoobraznosti ih ispolzovaniya pri formirovanii slozhnyh kompostov. Nauchnyj zhurnal KubGAU, No. 101 (7), 1-21.

10. Ozhygyna, S. B., Ozhygyn, D. S., et al. (2016). Monitoring sostoyaniya ustoychyvosti karernyh otkosov. Interekspo Geo-Sibir', pp. 161-166.

11. Korobanova, T. N. (2015). Monitoring opasnyh geodinamycheskih protsessov pry formiovanii otvala fosfogypsa Balakovskogo filiala JSC “Apatyt”. Gorny informatsionno-analitichesky byulleten (nauchno-tehnychesky zhurnal), No 4, 405-408.

12. Kutepov, Yu. Y., Kutepova, N. A., et al. (2013). Organizaciya i provedenie monitoringa bezopasnosti pry formirovanii otvalov fosfogypsa. Gorny informatsionno-analitichesky byulleten (nauchno-tehnychesky zhurnal), No 5, 68-72.

13. Plyatsuk, L. D., Chernysh, Ye. Yu., Yakhnenko E. N., \& Trunova, I. A. (2015). Systemny podhod k ekologycheskomu monitoringu v rajone razmeshcheniya otvala fosfogypsovyh othodov. Ekologicheskiy vestnyk (Minsk), No 4 (34), 77-85.

14. Didora, V. G., Smaglij, O. F., et al. (2013). Metodyka naukovyh doslidzhen v ahronomiyi: navch. posib. Centr uchbovoyi literatury. Kyiv, Ukraine.

15. Kolesnikov, M. P. (2001). Formy kremniya v rasteniyah. Uspekhi biologicheskoy khimii, Vol. 41, 301-333. 